\title{
Information Needs of Buffalo Farmers in Haryana
}

\author{
Kamal Kumar $^{1 *}$, Mahesh Chander', V. B. Dixit ${ }^{3}$, Hema Tripathi ${ }^{3}$, \\ D. Bardhan ${ }^{2}$ and Medhram Verma
}

${ }^{1}$ Division of Extension Education, Indian Veterinary Research Institute, Izatnagar, Bareilly, Uttar Pradesh (India)

${ }^{2}$ Division of Livestock Economics and Statistics, Indian Veterinary Research Institute, Izatnagar, Bareilly, Uttar Pradesh (India)

${ }^{3}$ Central Institute for Research on Buffalo, Hisar, Haryana (India)

*Corresponding author

\section{A B S T R A C T}

\section{Keywords}

Information needs, Buffalo farmers, Haryana, Breeding, Feeding, Healthcare

Article Info

Accepted:

20 October 2020

Available Online:

10 November 2020
The present study was carried out in Haryana, farmers with at least one adult female buffalo were selected randomly to arrive at a total sample size of 120 farmers. An ex-post facto research design was used in the present study. The responses for information needs of the buffalo farmers were retrieved on three point scale viz. most needed, needed and not needed. More than half $(56.70 \%)$ of the respondents fell in the medium information needs category while 22.50 per cent had low information need whereas 20.80 per cent were in high information needs category. The most important perceived information needs of the farmers included feeding, breeding, healthcare, market, farm credit and management. Information needs regarding feeding was ranked first as revealed by mean score (2.97) followed by breeding (2.82), healthcare (2.81), market (2.70), farm credit (2.49) and management (2.09) and were ranked second, third, fourth, fifth and sixth, respectively.

\section{Introduction}

Wijngaert (1999) conceptualized that needs for information consists of the process of perceiving a difference between an ideal state of knowledge and the actual state of knowledge. In the present study, perceived information needs refer to scientific buffalo husbandry practices on which respondents sought information.

The present human society is living in an information age and as a consequence, man has become more and more information conscious. More and more people deliberately seek information and it has become an integral part of human activity especially in the area of education, research and development, animal husbandry practices (e.g. castrations, dehorning, and marketing of animals).

The information must be relevant and meaningful to farmers, in addition to being packaged and delivered in a way preferred by them (Diekmann et al., 2009). Context- 
specific information could have higher impacts on the adoption of technologies and increase farm productivity for marginal and small agricultural landholders (Sammadar, 2006). An analysis of the NSSO 2003 survey showed that small and marginal farmers accessed less information and from fewer sources than medium and large scale farmers in India (Adhiguru et al., 2009).

Animal health information is of potential importance not only to the farm business but potentially also to animal welfare and public health. It is against this background that the field of buffalo husbandry is not an exception, in the need for timely delivery of complete and relevant information. This is because buffalo farmers have varying needs that range from information on the disease status of animals which is very crucial and can contribute to a large number of herd die off when ignored or pose as a threat to the wellbeing of humans.

Buffalo farmers also need information on good animal husbandry practices, new emerging technologies, market-related information, and information on livestock policies. The assessment of the information needs and seeking behavior of buffalo farmers is essential for assisting them to access and use information resources required for high production levels and equally to assist the relevant authorities in charge of disseminating information to come up with better implementation strategies.

\section{Materials and Methods}

The present study was carried out purposively in Haryana because the state is the native tract of best buffalo breed of the world i.e. "Murrah" buffalo. Haryana possesses a significant number of buffalo population and it is on the increasing trend. In the total livestock population of the state, buffalo contributes 69.00 per cent. The state is second highest in per capita milk availability i.e., 930 g/day (BAHS, 2017).

Haryana state is divided into two agroclimatic zones i.e. eastern and western zones which comprise 15 and 6 districts, respectively. Two districts from zone I and one district from zone II was selected randomly. As there are 15 districts in the zone I so to give proportional representation to both the zones, two districts were selected from zone I. Two blocks from each randomly selected district were selected randomly. Thus, a total of six blocks were studied. From each selected block, two villages were selected randomly. Thus, four villages from each district to a total of twelve villages constituted the study area. From each selected village, a sampling frame comprising the list of buffalo farmers having at least one adult female buffalo was prepared with the help of the veterinary officer. From the listed farmers, ten buffalo farmers were selected randomly. Hence, ten farmers from each village were selected randomly to arrive at a total sample size of 120 farmers. The variables under study were selected on the basis of an extensive review of literature related to the topic of research and consultation with experts. An expost facto research design was used in the present study.

\section{Results and Discussion}

Perceived information needs of the buffalo farmers were classified under sub-headings viz., management, breeding, healthcare, feeding, farm credit and market. Data on perceived information needs on various areas of improved buffalo husbandry practices were collected on three-point continuum with maximum score of three and minimum score of one where one stood for not needed and three for most needed information. The findings are presented as follows: 
As evident from Table 1, on the basis of total score of information needs it was found that more than half $(56.70 \%)$ of the respondents fell in medium information needs category, while 22.50 and 20.80 percents were categorized as respondents having low and high information needs. The results were in line with the finding of Meena et al., (2014) who found that most of the respondents had medium level of perceived information needs.

On the basis of mean and percentage of total information needs score, areas of information needs were ranked. It was found that feeding was the area with highest information needs mean score 2.97 and ranked first, followed by breeding (2.82), healthcare (2.81), market (2.70), farm credit (2.49) and general management (2.09) which were ranked second, third, fourth, fifth and sixth, respectively. The results were in accordance with the finding of Kanthi (2013), Balaraju et al., (2014), Raina (2017) and Singh et al., (2018) who observed that feeding, breeding, healthcare, general management, market and farm credit were the major areas on which respondents needed information (Table 1-3).

\section{Information needs on management}

Results in Table 9 revealed that a sizeable population of the respondents $(40.00 \%)$ belonged to low perceived information needs on general management followed by 38.30 and 21.70 percent respondents who had high and medium perceived information needs, respectively. The results were in concurrence with the findings of Devaki and Senthilkumar (2013), who conducted a study in Tamilnadu and found that in perceived information needs of the farm women, general management was ranked sixth with minimum mean percentage of 59.93 .

\section{Information needs on breeding}

The perceived information needs of the buffalo farmers on various aspects of breeding are shown in Table 4. Results revealed that majority of the respondents needed information on importance of AI and methods of breeding for improving the genetic potential of the buffalo, as clear from their mean scores of 2.93 and 2.91 respectively.

Table.1 Distribution of respondents according to their perceived information needs

\begin{tabular}{|c|c|c|}
\hline Information needs & Frequency $(\mathbf{n = 1 2 0})$ & \\
\hline Low & $27(22.50)$ & Mean total score $=\mathbf{1 0 1 . 6 9}$ \\
\hline Medium & $68(56.70)$ & SD $=\mathbf{3 . 8 1 7}$ \\
\hline High & $25(20.80)$ & \\
\hline
\end{tabular}

Table.2 Ranking of major areas of information needs of buffalo farmers

\begin{tabular}{|c|c|c|}
\hline Major areas & Mean score & Rank \\
\hline Breeding & 2.82 & II \\
\hline Market & 2.70 & IV \\
\hline Feeding & 2.97 & I \\
\hline Healthcare & 2.81 & III \\
\hline General management & 2.09 & VI \\
\hline Farm credit & 2.49 & V \\
\hline
\end{tabular}


Table.3 Distribution of respondents according to their information needs on management

\begin{tabular}{|c|c|c|c|c|}
\hline Management & $\begin{array}{c}\text { Most } \\
\text { needed }\end{array}$ & Needed & $\begin{array}{c}\text { Not } \\
\text { needed }\end{array}$ & $\begin{array}{c}\text { Mean } \\
\text { score }\end{array}$ \\
\hline Scientific method of buffalo rearing and its practice & $0(0.00)$ & $84(70.00)$ & $36(30.00)$ & 1.70 \\
\hline Breeds of buffalo and its importance & $0(0.00)$ & $87(72.50)$ & $33(27.50)$ & 1.73 \\
\hline Care of dam before, during and after parturition & $0(0.00)$ & $68(56.67)$ & $52(43.33)$ & 1.57 \\
\hline Care and management of new born calf & $54(45.00)$ & $56(46.67)$ & $10(8.33)$ & 2.37 \\
\hline Importance of colostrum & $46(38.33)$ & $67(55.83)$ & $7(5.84)$ & 2.33 \\
\hline Care and management of milch buffalo & $46(38.33)$ & $60(50.00)$ & $14(11.67)$ & 2.27 \\
\hline Method of disposal of male buffalo & $47(39.16)$ & $25(20.84)$ & $48(40.00)$ & 1.99 \\
\hline Housing system and cleaning practice & $50(41.67)$ & $22(18.33)$ & $48(40.00)$ & 1.99 \\
\hline Buffalo insurance & $58(48.33)$ & $52(43.33)$ & $10(8.34)$ & 2.40 \\
\hline Clean milk production & $64(53.34)$ & $56(46.66)$ & $0(0.00)$ & 2.53 \\
\hline
\end{tabular}

Figures in parenthesis indicate percentage

Table.4 Distribution of respondents according to their information needs on breeding

\begin{tabular}{|c|c|c|c|c|}
\hline Breeding & Most needed & Needed & $\begin{array}{c}\text { Not } \\
\text { needed }\end{array}$ & $\begin{array}{c}\text { Mean } \\
\text { score }\end{array}$ \\
\hline $\begin{array}{c}\text { Selection and importance of male and female buffalo for } \\
\text { breeding }\end{array}$ & $108(90.00)$ & $12(10.00)$ & $0(0.00)$ & 2.90 \\
\hline $\begin{array}{c}\text { Methods of breeding for improving the genetic potential } \\
\text { of the buffalo }\end{array}$ & $111(92.50)$ & $7(5.84)$ & $2(1.66)$ & 2.91 \\
\hline Importance of AI & $112(93.33)$ & $8(6.67)$ & $0(0.00)$ & 2.93 \\
\hline Importance of high genetic merit bull & $61(50.83)$ & $58(48.34)$ & $1(0.83)$ & 2.50 \\
\hline Heat detection & $106(88.33)$ & $14(11.67)$ & $0(0.00)$ & 2.88 \\
\hline
\end{tabular}

Figures in parenthesis indicate percentage

Table.5 Distribution of respondents according to their information needs on healthcare

\begin{tabular}{|c|c|c|c|c|}
\hline Healthcare & $\begin{array}{c}\text { Most } \\
\text { needed }\end{array}$ & Needed & $\begin{array}{c}\text { Not } \\
\text { needed }\end{array}$ & $\begin{array}{c}\text { Mean } \\
\text { score }\end{array}$ \\
\hline $\begin{array}{c}\text { Information about vaccine preventable } \\
\text { diseases like HS, FMD, BQ and Brucella }\end{array}$ & $112(93.33)$ & $8(6.67)$ & $0(0.00)$ & 2.93 \\
\hline $\begin{array}{c}\text { Information about preventive vaccines } \\
\text { available for buffaloes }\end{array}$ & $63(52.50)$ & $57(47.50)$ & $0(0.00)$ & 2.53 \\
\hline $\begin{array}{c}\text { Information on diseases of zoonotic } \\
\text { importance }\end{array}$ & $115(95.83)$ & $5(1)$ & $0(0.00)$ & 2.96 \\
\hline $\begin{array}{c}\text { Prevention and destruction of internal and } \\
\text { external parasites and its importance }\end{array}$ & $117(97.50)$ & $3(2.50)$ & $0(0.00)$ & 2.98 \\
\hline $\begin{array}{c}\text { Information about diseases of buffaloes } \\
\text { and home remedies for them }\end{array}$ & $62(51.67)$ & $58(48.33)$ & $0(0.00)$ & 2.52 \\
\hline Proper disposal of the carcass & $115(95.83)$ & $5(1)$ & $0(0.00)$ & 2.96 \\
\hline
\end{tabular}

Figures in parenthesis indicate percentage 
Table.6 Distribution of respondents according to their information needs on feeding

\begin{tabular}{|c|c|c|c|c|}
\hline Feeding & $\begin{array}{c}\text { Most } \\
\text { needed }\end{array}$ & Needed & $\begin{array}{c}\text { Not } \\
\text { needed }\end{array}$ & $\begin{array}{c}\text { Mean } \\
\text { Score }\end{array}$ \\
\hline $\begin{array}{c}\text { Feeding of pregnant buffalo and its } \\
\text { importance }\end{array}$ & $116(96.67)$ & $4(3.33)$ & $0(0.00)$ & 2.97 \\
\hline Importance of mineral mixture & $117(97.50)$ & $3(2.50)$ & $0(0.00)$ & 2.98 \\
\hline Importance of concentrate feeding & $117(97.50)$ & $3(2.50)$ & $0(0.00)$ & 2.98 \\
\hline Preparation of silage & $120(100.00)$ & $0(0.00)$ & $0(0.00)$ & 3.00 \\
\hline Feeding of young calves & $115(95.83)$ & $5(1)$ & $0(0.00)$ & 2.96 \\
\hline Feeding of heifer & $116(96.67)$ & $4(3.33)$ & $0(0.00)$ & 2.97 \\
\hline Fodder production for lean period & $119(99.16)$ & $1(0.84)$ & $0(0.00)$ & 2.99 \\
\hline Balance feeding & $117(97.50)$ & $3(2.50)$ & $0(0.00)$ & 2.98 \\
\hline
\end{tabular}

Figures in parenthesis indicate percentage

Table.7 Distribution of respondents according to their information needs on market

\begin{tabular}{|c|c|c|c|c|}
\hline Market & $\begin{array}{c}\text { Most } \\
\text { needed }\end{array}$ & Needed & $\begin{array}{c}\text { Not } \\
\text { needed }\end{array}$ & $\begin{array}{c}\text { Mean } \\
\text { score }\end{array}$ \\
\hline Selling of milk on better remunerative prices & $118(98.33)$ & $2(1.67)$ & $0(0.00)$ & 2.98 \\
\hline Importance of value edition & $58(48.33)$ & $32(26.67)$ & $0(0.00)$ & 2.48 \\
\hline Purchasing of animal from reliable source & $66(55.00)$ & $54(45.00)$ & $0(0.00)$ & 2.55 \\
\hline $\begin{array}{c}\text { Animal purchase with suitable record and } \\
\text { certificates }\end{array}$ & $110(91.67)$ & $10(8.33)$ & $0(0.00)$ & 2.92 \\
\hline Information on government schemes & $72(60.00)$ & $48(40.00)$ & $0(0.00)$ & 2.60 \\
\hline
\end{tabular}

Figures in parenthesis indicate percentage

Table.8 Distribution of respondents according to their information needs on farm credit

\begin{tabular}{|c|c|c|c|c|}
\hline Farm credit & Most needed & Needed & Not needed & Mean score \\
\hline Source of credit availability & $78(65.00)$ & $42(35.00)$ & $0(0.00)$ & 2.65 \\
\hline Interest and repayment & $70(58.33)$ & $50(41.67)$ & $0(0.00)$ & 2.58 \\
\hline Rules and procedure & $65(54.16)$ & $54(45.00)$ & $1(0.84)$ & 2.53 \\
\hline Mode of disbursement & $72(60.00)$ & $48(40.00)$ & $0(0.00)$ & 2.60 \\
\hline Loan related information & $16(13.33)$ & $100(83.34)$ & $4(3.33)$ & 2.10 \\
\hline
\end{tabular}

Figures in parenthesis indicate percentage

Table.9 Distribution of respondents according to their area of perceived information needs

\begin{tabular}{|c|c|c|c|c|c|c|}
\hline Category & $\begin{array}{c}\text { Management } \\
\mathbf{n = 1 2 0}\end{array}$ & $\begin{array}{c}\text { Breeding } \\
\mathbf{n = 1 2 0}\end{array}$ & $\begin{array}{c}\text { Healthcare } \\
\mathbf{n = 1 2 0}\end{array}$ & $\begin{array}{c}\text { Feeding } \\
\mathbf{n = 1 2 0}\end{array}$ & $\begin{array}{c}\text { Market } \\
\mathbf{n = 1 2 0}\end{array}$ & $\begin{array}{c}\text { Farm credit } \\
\mathbf{n}=\mathbf{1 2 0}\end{array}$ \\
\hline Low & $48(40.00)$ & $9(7.50)$ & $0(0.00)$ & $0(0.00)$ & $0(0.00)$ & $46(38.30)$ \\
\hline Medium & $26(21.70)$ & $0(0.00)$ & $74(61.70)$ & $6(5.00)$ & $58(48.30)$ & $15(12.50)$ \\
\hline High & $46(38.30)$ & $111(92.50)$ & $46(38.30)$ & $114(95.00)$ & $62(51.70)$ & $59(49.20)$ \\
\hline
\end{tabular}

Figures in parenthesis indicate percentage 
Data in Table 9 revealed that majority $(92.50 \%)$ of the respondents belonged to high level of perceived information needs on breeding, while the remaining 7.50 per cent had low information needs. The results were in accordance with the observation of Singh et al., (2016) who conducted study in Punjab and reported that 64.70 per cent of the farmers sought information on animal breeding. The same results were reported by Devaki and Senthilkumar (2013) who conducted a study in Tamilnadu and found that with regard to perceived information needs of the farm women, breeding was ranked second with a mean percentage of 81.33 .

\section{Information needs on healthcare}

Data pertaining to perceived information needs of the buffalo farmers on various aspects of healthcare is presented in Table 5 and it is apparent from the table that majority of the respondents needed information on prevention and elimination of internal and external parasites followed by information on zoonotic diseases and proper disposal of the carcass, as evident from the mean scores of $2.98,2.96$ and 2.96 respectively.

Data in table 9 revealed that most $(61.70 \%)$ of the respondents had medium level of perceived information needs on healthcare and remaining 38.30 per cent had high information needs. The results were in concurrence with the findings of Rezvanfar et al., (2007), who conducted study in Iran and concluded that farm women needed more information on healthcare and Phand et al., (2009) stated that information on health management aspect was one of the priorities of the farmers.

\section{Information needs on feeding}

The perceived information needs of the buffalo farmers on various aspects of feeding are indicated in table 6. Data revealed that majority of the respondents needed information on preparation of silage and fodder production for lean period, as apparent from the mean scores of 3.00 and 2.99, respectively.

Data in table 9 showed that majority (95.00 $\%$ ) of the respondents had high perceived information needs on feeding while remaining 5.00 per cent had medium perceived information needs on feeding.

The results were in line with the finding of Singh et al., (2018), who conducted a study to examine the information needs of farmers using mKisan services in Uttar Pradesh with respect to different dairy husbandry practices and revealed that farmers had higher information needs about feeding practices which was seen from weighted mean score of 2.20 .

\section{Information needs on market}

As shown in Table 7, the perceived information needs of the buffalo farmers on various aspects of market envisages that majority of the respondents needed information on selling of milk on better remunerative prices and animal purchase with suitable record and certificates, which are evident from their mean scores 2.98 and 2.92, respectively.

Table 9 clearly shows that more than half $(51.70 \%)$ of the respondents belonged to high level of perceived information needs on market related information followed by 48.30 per cent who belonged to medium category. The results were in line with the observation of Singh et al., (2016) who conducted study in Punjab and reported that majority of the farmers $(70.58 \%)$ needed information on different subsidy schemes of the government. 


\section{Information needs on farm credit}

The perceived information needs of the buffalo farmers on various aspects of farm credit are shown in Table 8. It is apparent that majority of the respondents needed information on source of credit availability and mode of disbursement as evident from their mean scores of 2.65 and 2.60 respectively.

Data in Table 9 reveals that almost half (49.20\%) of the respondents belonged to high level of perceived information needs on farm credit related information followed by 12.50 per cent belonged to medium category and 38.30 per cent belonged to low information needs. Similar results were reported by Babu (2008) who found that 51.94 per cent of the respondents needed information on credit organization. However, the results were not in agreement with the finding of Devaki and Senthilkumar (2013) who conducted a study in Tamilnadu and found that in perceived information needs of the farm women, farm credit was ranked first.

In conclusion to fulfill the information needs of the farmers' additional number of multipronged information channels needs to be created. Organizing more number of informal group meetings, use of print media and television programmes, use of interactive two way platforms for providing context specific and need based information about improved buffalo husbandry practices by different players who are working for buffalo development in the state, can be effective. As seen from present study farmers needed more information on market and farm credit that can be fulfilled by concerned stakeholder viz., banks, farmers' cooperatives and SDAH personnel by organizing special meetings, dedicated stalls in farmers' fairs, use of print media and television programmes.

\section{References}

Adhiguru, P., Birthal, P.S. and Kumar, G.P. 2009. Strengthening Pluralistic Agricultural Information Delivery Systems in India. Agricultural Economics Research Review, 22 (1): $71-79$.

Babu, B. 2008. Information needs of women self-help group involved in dairy farming for capacity building. M.V.Sc. Thesis, SVVU, Tirupati, Andhra Pradesh, India.

Balaraju, B.L., Khandekar, P., Chander, M. and Devi, L. 2014. Perceived training needs of livestock farmers in Karnataka. Journal of Veterinary Science and Technology, 5(3): 153.

Devaki, K. and Senthilkumar, K. 2013. Relationship between different characteristics of livestock farm women on information need perception. International journal of Science, Environment and Technology, 2(5): 981-988. Accessed through http://www.ijset.net/journal/174.pdf on 20.5.2019

Diekmann, F., Loibl, C. and Batte, M.T. 2009. The Economics of Agricultural Information: Factors Affecting Commercial Farmers Information Strategies in Ohio. Review of Agricultural Economics, 31(4): 853-872. Government of India. 2017a. Basic Animal Husbandry and Fisheries Statistics. Ministry of Agriculture and Farmers Welfare, Department of Animal Husbandry, Dairying and Fisheries, Krishi Bhawan, New Delhi. Accessed through

http://dahd.nic.in/sites/default/filess/Bas icAnimal Husbandry and Fisheries Statistics 2017 (English version) _5.pdf on 05.09.2018

Kanthi, S.S., 2013. Effectiveness of Community Radio as a Means of 
Knowledge Dissemination among Women Dairy Farmers. M.V.Sc Thesis, SVVU, Tirupati, Andhra Pradesh, India.

Meena, B.S., Kumar, R. and Singh, A. 2014. Effectiveness of multimedia digital video disk on knowledge gain of improved dairy farming practices. Indian Journal of Dairy Science, 67(5): 442-445.

Phand, S., Tiwari, R. and Sharma, M.C. 2009. Development of need based Animal Health Information System (AHIS) for Veterinary professionals and students. Indian Veterinary Research Institute, Izatnagar.

Raina, V., Sharma, N., Khajuria, S., Kumar, K., Choudhary, S., Syed, Z. and Hussain, K. 2017. Training Needs of Dairy Farmers. International Journal of Agriculture Environment and Biotechnology, 10(2): 245-251.

Rezvanfar, A., Moradnezhai, H. and Vahedi, M. 2007. Information needs of farm women relate to dairy farming and home management in Ilam State of Iran. Livestock Research for Rural Development, Volume 19, Article \#113. Retrieved from http://www.lrrd.org/lrrd19/8/rezv19113. htm on 29.5.2019

Sammadar, A. 2006. Traditional and PostTraditional: A Study of Agricultural Rituals in Relation to Technological Complexity among Rice Producers in Two Zones of West Bengal, India. Journal of Culture and Agriculture, 28(2): 108-121.

Singh, N., Malhotra, P. and Singh, J. 2016. Information needs and seeking behaviour of dairy farmers of Punjab. Indian Journal of Dairy Science, 69(1): 98-104.

Singh, P.K., Tiwari, R. and Dutt, T. 2018. Dairy Husbandry needs of farmers in different agro climatic zones of Uttar Pradesh. Indian Journal of Animal Sciences, 88(8): 972-976.

Wijngaert, L.V.D. 1999. Matching media Information need and new media choice. Telematica Institute Fundamental Research Series, No.: 4 (TI/FRS/004), Enschede, the Netherland, pp: 124. Accessed through https: // dspace. library. uu. nl/ bitstream /handle /1874/ 1724/full.pdf on 14.11.2018

\section{How to cite this article:}

Kamal Kumar, Mahesh Chander, V. B. Dixit, Hema Tripathi, D. Bardhan and Medhram Verma 2020. Information Needs of Buffalo Farmers in Haryana. Int.J.Curr.Microbiol.App.Sci. 9(11): 2858-2865. doi: https://doi.org/10.20546/ijcmas.2020.911.345 